\title{
Adverbs of Time in Arabic and English: Comparative Study
}

\author{
Mohamed Farhat Mehdi (Corresponding author) \\ Department of Academic Affairs, University College of Mother and Family Sciences \\ Ajman, UAE \\ E-mail: farhat.mehdi@ucmother.ac.ae
}

Mazen Jaradat

Department of Arabic and Islamic Studies, Ajman University

Ajman, UAE

Received: January 26, 2021

Accepted: February 27, 2021 Published: February 28, 2021

doi:10.5296/ijl.v13i1.18254

URL: https://doi.org/10.5296/ijl.v13i1.18254

\begin{abstract}
Adverbs are words that are used to change, modify or qualify several types of other words including adjectives, verbs, or other adverbs. There are five basic types of adverbs in the English language, namely that of Manner, Time, Place, Frequency, and Degree. In the Arabic language, there are just two adverbs namely that of Time and Place. This research aimed to prove that the adverb of time exists in both Arabic and English languages and to compare and state the similarities and differences between the two languages. Most importantly, to show which were more the similarities or the differences? The results showed that the similarities were more than the differences despite the fact that the two languages are not from the same family.
\end{abstract}

Keywords: Adverb of time, Grammatical study, Declinable or indeclinable, Inflectional and non-inflectional adverbs

\section{Introduction}

There are many differences between Arabic language and English language in grammar, sentence structures, quality and length of consonants. Arabic language belongs to the family of the Semitic languages, so its rules are completely different from the rules of English language, which belongs to Germanic family languages. Arabic words contain a triple root, as 
all words and all parts of speech are formed by combining consonants with triple roots and fixed vowels. In Arabic, letter sounds depend on the consistency of the sentence, and the learner must know how to pronounce solar letters and lunar characters as well. The Arabic alphabet contains twenty-eight characters, while the English alphabet contains twenty-six letters. Many people who learn Arabic may make mistakes as a result of the absence of patterns in the English language that allow them to distinguish between nouns, verbs, adverbs or adjectives. Given the many differences between the Arabic and English languages, learners in both Arabic and English find it difficult to understand the intricacies of individual language.

We expected that this research would be significant for both the instructors and the learners by providing them with a good descriptive analysis of the adverbs of time in both languages. By examining the similarities and the differences between the two languages, instructors could be able to predict the difficulties that might face the learners based on the contrastive analysis theory. Therefore, to explicate the adverb of time in both Arabic and English languages, 13 Arabic genuine adverbs of time were used to be compared and contrasted to their English counterparts to describe their provisions in terms of sections, case-ending, significance, deletion, presentation and delay in sentences, and to identify the similarities and differences in the two languages in the adverb of time, and to analyze this to reach results that are answers to the following research questions:

1. What is the similarity and difference between the two languages in adverb of time?

2. Which is more diverse similarity or difference? What is the significance of that?

3. Is there a relationship between the two languages historically and factually?

English has five basic types of adverbs namely: adverb of time, place, frequency, degree and manner. Adverbs in English provide a deeper description of verbs in sentences. Arabic has two types of adverbs namely: adverb of time and adverb of place. The other similar types, which are adverbs in English, are not adverbs in Arabic. In English, the adverb of time provides more information about when a verb takes place. Adverbs of time are usually placed at the beginning or end of a sentence. When the adverb is of particular importance to express the moment, it is put at the start of a sentence. Some adverbs of time are: never, lately, just, always, recently, during, yet, soon, sometimes, usually, so far. Examples: "so far, the contractor built three stores"; "I haven't seen my friend lately".

The Arabic language differentiates between time and adverb. Every verb that is formed indicates an action and time, and therefore, time is clarified by the form of the verb (past, present, and imperative), so every form of these verbs indicates an action in time, and so are all the verbs.

In the Arabic language, there are words that denote time and called the name "noun" of time and this is a morphological connotation. These nouns are derived from the verbs and each starts with the letter "Meem”, “p” For example, the sentence "مطلع الثمس الساعة السادسة", "The appearance of the sun is at six o'clock", the word "مطلع" indicates the time of the sun rising. It 
is a morphological term related to the structure of the word and is grammatically treated as any other noun.

As for the adverb or the locative adverb, it is a grammatical term related to the structure of the sentence.

\section{Literature Review}

\subsection{Contrastive Analysis}

This study was based of contrastive analysis theory. Contrastive Analysis means the comparison of two languages by focusing on the differences and similarities between them. Contrastive Analysis was developed in the USA as part of English Language Teaching (ELT) movement for a better way of teaching English and making learning process much easier and faster.

In 1945, the American linguist C. C. Fries introduced the study of Contrastive Linguistics. He stated that, "the most effective teaching materials are those that are based upon a scientific description of the language to be learned, carefully compared with a parallel description of the native language of the learner". (Fries 1945: 9).

In 1957, Robert Lado continued this supposition in his book "Linguistics Across Cultures" through which he presented Contrastive Analysis Hypothesis. He proposed that, "Individual tends to transfer the forms and meanings and the distribution of forms and meanings of their native language and culture to the foreign language- both productively when attempting to speak the language and act in the culture and receptively when attempting to grasp and understand the language and culture". (Lado 1957: 2).

In other words, Lado claimed that learners of a foreign language fall back on their mother tongue and they are influenced by it. The learners tend to transfer sounds, words and grammatical structures of their native language to the foreign language. Lado added that if a sound, a word or a structure in the foreign language were similar to that in the native language, it would be easy for learners to learn because they would be a process of 'positive transfer' or 'facilitation'. However, he claimed that points of difference between the two languages would be difficult for learners to learn, as there would be a process of 'negative transfer' or 'interference'. (ibid).

\subsection{Adverbs}

Adverbs are viewed as a challenging aspect of language learning, because of the problems that the learners face. These problems are dealt with differently. Osborne (2008), Rankin (2010) indicated that these problems are related to syntactic reasons such as the placement of the adverb, or the type of the adverb. Hsue-Hueh Shih (2000) pointed out that problems are related to overuse or underuse of particular adverbs.

Jackendoff (1972:47) stated that, "The adverb is perhaps the least studied and most maligned part of speech", because at that time just few studies on adverbs were conducted. 
Cinque (1999) was the first to investigate the places of adverbs using cross-linguistic data from English, French, Hebrew and Chinese. He said that adverbs have a fixed universal hierarchy, but when they occur in two different positions and meanings, then movement has occurred.

Karin. C. Ryding (2005:290) said that, "Adverbial expressions of time fall into four categories: basic adverbs, single nouns and adjectives in the accusative, compound time demonstratives and phrases". According to her, basic adverbs signify specific points in time and tend to persist in one form without changing for case or definiteness. (ibid)

Pascual Pérez-Paredes and María Sánchez-Torne, (2014:180) indicated that, "The mastery of adverbs in spoken and written communication contributes greatly to achieving a native-like command of the language".

Marcella Frank (1972: 141) stated that adverbs are of three kinds: (i) Adverbs of Manner, (ii) Adverbs of Place and (iii) Adverbs of Time. On the functional level, Marcella Frank classified adverbs into five types: (i) Sentence Adverbs, where the adverb is looked upon as modifying the whole sentence rather than the verb, e.g. presumably, actually, fortunately. (ii) Conjunctive Adverbs, where they establish a relationship between one sentence or clause and the preceding sentence or clause, e.g. besides, otherwise, consequently, then, nevertheless. (iii) Explanatory Adverbs, where they illustrate or enumerate, namely. (iv) Relative, Interrogative Adverbs, they are When, Where, Why, How. The Relative adverbs are used to introduce adjective clauses while the Interrogative Adverbs are used in question or in noun clauses derived from questions. (v) Exclamatory Adverbs-How, where they are used with adjectives and adverbs. (ibid)

\section{Adverbs in Arabic and English}

The adverb in Arabic language is the container, and the adverb of everything is its container (Lisan Al-Arab.) The adverb in the grammar books is classified among accusatives, and it is called a locative adverb because in which the action takes place. The action is indicated by the verb or quasi-verb as active participle, and passive participle, therefore, in grammar it is an accusative participle on the discretion of "في" "in" and is mentioned to indicate the time or place of the act, but if it is not at the discretion of "in" therefore, it is not an adverb.

It is treated like other nouns. For example, the word "يوم", "day" can be an adverb or not. If it is considered " في " ذهبت يو الجمعة إلى المسجد" "in” " then, it is an adverb such as "I went to the mosque on Friday". If it is not considered "في" "في "نin", then it is not an adverb, for example,

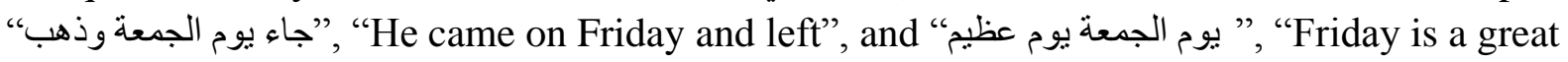

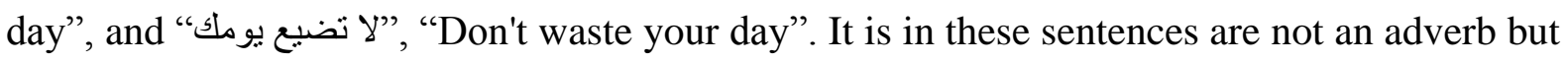
it is: a subject, a primate and an object respectively.

\section{The Types of the Adverb “ أنواع الظرف"}

The adverb of time indicates the time when the action occurred, and the adverb of the place indicates the location of the act.

In this research, the adverbs of time in both Arabic and English were dealt with. 


\subsection{The Adverb in Arabic Is Vague and Limited}

\subsubsection{The Vague Adverb}

The vague adverb is indicative of an unlimited amount of time, such as: "أمد ", "amad",

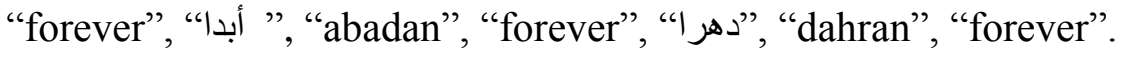

\subsubsection{The Limited}

Indicates a certain estimated time, such as: "ساعة", “hour”, “يوم"،, “day”, “"شهر", “month”, and “ة' " “year”.

\subsection{The Adverb in Arabic Is Either Declinable or Indeclinable}

\section{”الظرف في العربية متصرف وغير متصرف،}

\subsubsection{The Declinable}

The declinable are the nouns that can be used as adverbs, and cannot be used as adverbs such as: hour, day, week, month, year. For examples: His Almighty said: “"إن الساعة لآتية لا ريب فيها ") ", “The hour is definitely coming", and "هذا يوم ينفع الصادقين صدقهم". "This is a day that will benefit the truthful ones", "The Hour" is an adverb of time, but it came up because it is the name of "Ana," "The Day", an adverb of time, but it came up because it was a predicate item for the primate.

English has similar usages: nouns can be used as adverbs. Example: "he will come tomorrow”, “ "سيأتي غداً", “Tomorrow is another day”, “غدا نهار آخر ". In the first sentence "tomorrow" is an adverb, while it is a noun in the second sentence.

\subsubsection{The Indeclinable Adverb Is of Two Kinds}

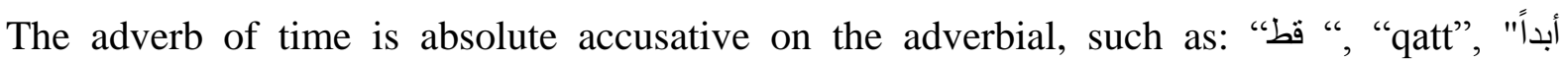

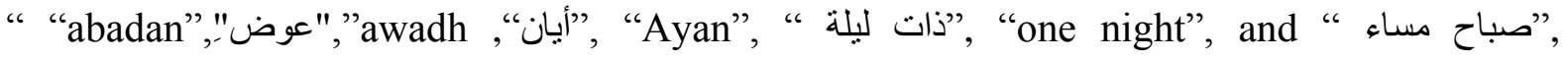
"morning evening".

What requires accusative on an adverbial, or genitive with one of the prepositions such as:

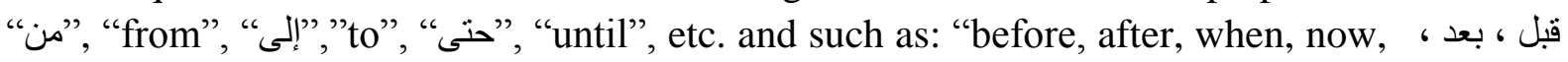

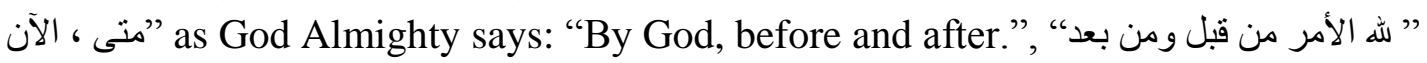

In English Language, however, an adverb of time is a word which describes: when, for how long, or how frequently a certain action occurred. In the past, words like yesterday, last week, the day before, etc. are used, for example: "George bought a car yesterday", “انترى جورج سيارة بالامس ". In the present words such as when, still, while, yet, etc. are used, for example, "They

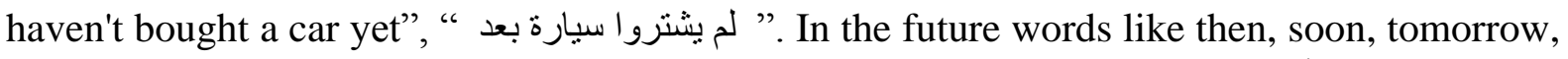
next week, etc. are used, for example: "I will buy a house soon”, “سأثنري بيتا قريبارة". Adverbs of time in these examples are placed at the end of the sentences and is most often the case, but sometimes the adverbs of time are placed at the beginning of the sentences to put an extra emphasis on the time or duration being described. They are usually offset by a comma if appearing at the beginning of the sentence, although this is not always necessary. Examples: "Next year, I'm going to hajj” "السنة القادمة سأذهب للحج" (Emphasizes a point in time.) "Now, I 
have to sell the whole products and buy new machines.", الآن يجب عليّ أن أبيع كل المنتوجات" (Emphasizes now in a sequence of events.) "For 30 years, we've been friends, and not once have fought." (Emphasizes the duration of time.)

In Arabic an adverb of time indicates the time at which an action or event occurred, for example: “" سافرت ليلا", "I travelled at night”, and “ عملت سبع ساعات", "I worked seven hours”: here the adverb came later than or after the verb, and this is the original way. But in " قبل طلوع" "الثمس سافرت "I travelled before sunrise", and "Thursday I fasted”, the adverbs are placed in the beginning of the sentences for their importance. This is similar to English usage. In Arabic words that are used as adverbs have the priority to be placed in the beginning of the sentence because of their importance, for example: "منى نصر الله "When is the victory of Allah", مرساها"آيان "When will be its appointed time (the Hour)".

\section{Adverb in Terms of Case-Ending (إعراب)}

In Arabic the adverb is considered one of the accusatives and is called locative adverb, and the temporal adverb is absolute accusative, whether vague or limited as "I traveled at night" ,سافرت ليلاً،" on the condition that it includes the meaning of " في "، "in”, and if it does not include the meaning "in", then it is expressed according to its location and its factor.

\subsection{The Adverb Is Attached}

The adverb always needs something to be related to it, like the verb and its likeness, and it is similar to the preposition that needs something to be related to obligatory, and the related is either mentioned like: "I read an hour", “ قرأت ساعة " and "I missed a month", “غبت شهر " فر " obligatorily deleted such as: "the time of dawn, I traveled in it", “وقت الفجر سافرت فيه". The "وته" " time here is accusative and its attachment is omitted and estimated silently. In Arabic, this is called accusative on "working".

\section{What Deputize the Adverb}

In Arabic language there are words that deputize the adverb and are accusatives in the same way. They are as follows:

- The additive words (nouns added to others) "الكلمات المضافة اليه" which indicate the general: "مشيت كل اليوم", "I walked all day”. and "مرأت بعض اليه" "I read some time”.

- The description of the adverb, such as: "وقفت طويلا", "I stood long".

- Demonstrative noun like: “مشيت هذا اليوم", "I walked today”.

- The distinguished number by the adverb, such as: "سافرت ثناثين يوماً", "I traveled thirty days".

- The infinitive that includes the meaning of the adverb like: “جئنك صلاة العصر", "I came to you during Asr prayer".

In English there is no such deputize. 


\section{Ml Macrothink}

\section{Inflectional and Non-Inflectional Adverbs of Time}

Most adverbs are inflectional and changeable in Arabic except a number of concepts which are limited either to time or place.

The non-inflectional or fixed adverbs of time are words pertaining to the adverb and used only as adverb, namely:

\section{1 "إذا" "If”,}

- "إذإl", (if), is an adverb for the future that includes the meaning of the condition and is concerned with entering the verbal sentence. The verb with it is past in pronunciation, and future in meaning in most of its uses. It is used with the present tense less than with the past. The two verbs met with "if", "إذا", in the words of the following poem:

And the soul is willing if you desire it and if it returns to a little persuades

$$
\text { و النفس راغبة إذا رغبتها و إذا ترد إلى قليل تقنع }
$$

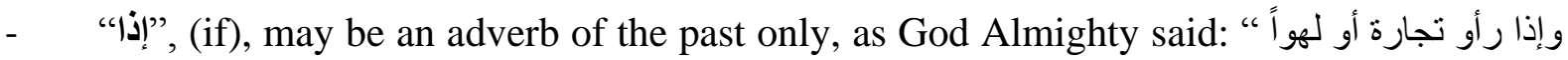
و "And when they see some merchandise or some amusement, they disperse heading to it".

- “إذإذ", (if), may be only adverbial that does not include the meaning of the condition such as: "الليل 2، 1، (الليل إذا يغشى و النهار إذا تجلى "by the night as it envelops and by the day as it appears in the brightness".

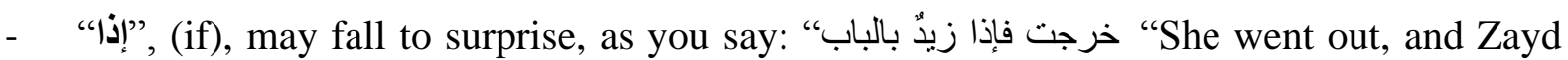
was at the door". Detailed explanation 4/97.

\section{2 "إذ "Because”, “When”}

فقد نصره الله إذْ أخرجه الذين “" could be an adverb for the past time, such as God Almighty said: إذَ"، " “for Allah did indeed help him when the disbelieves drove him out.”, and it may be an adverb for the future, as God Almighty says: "فسوف يعلمون إذ الأغلال في أعناقهم" (غافر 71/70) ", “They will come to know when iron collars will be rounded over their necks”.

“إذ” may not be an adverb in such cases as:

- In the position of the addition to it, like: "بعد إذ هديتنان ) ، "after you have guided us"

- In the location of the object, as in the Almighty’s saying “ “و الأعر اف 86), "and remember when you were but few".

- In the location of in place of as Almighty says "

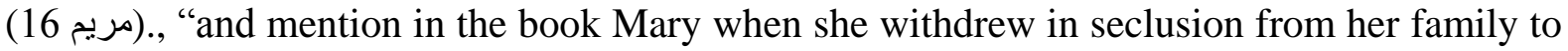
a place facing east".

- It is necessary to add to the sentences, and the sentence may be deleted and the " التنوين “"tanween" will remain in its place, such as: " عندئذ ", "then". 
- In the location of surprise as you say: “بينا زيدُ قائمٌ إذ رأى عمرً ”, “while Zaid is standing he sees Omar".

\section{3 “متى", “Matta” “When”}

" "متىى is an adverb of time indeclinable on stillness (absence of a vowel), and could be an accusative demonstrative noun based on adverbial: as " منى جئت ب ", "When did you come?". It can be genitive by "من وحتى ", "from and until”. When it comes conditioned, it is an adverbial, jussive and indeclinable on stillness and cannot be used in a genitive case.

English has similar adverb of time that tells when something happened. For example: "When Ali talks to his instructor, he is really happy”. "منى (عندما) تحدث علي الي معلمه كان حق سعيد".

\section{4 "أيان", “Ayaan” “When”}

It is an adverb for the future and is used as interrogative pronoun about time., and it is most frequently used in the areas of exaggeration, such as the words of God Almighty: "أيان يوم الدين" "When is the Day of Judgment" (القيامة 6) "ayaan is made of two words "ay" and "aan" which means "any time". The two concepts are reduced and became one. It may include the meaning of the condition, so the two verbs are put in the jussive case as in : “ أيان تجتهذْ تجذ نجاحاً ", “when you strive hard, you will find success".

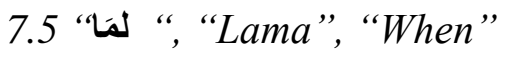

It is an adverb for past time that means "حين" or " when" or "since". It requires two sentences, both of which are past, such as: "لما زرتني أكرمتلك" "when you visited me, I honored you", and its place is accusative on the adverbial of its answer, and it is added to a sentence. Some scholars considered it a linking letter for the two sentences.

As Arabic, English has the same adverb namely "when". It is used to talk about the past, example: "When Sami bought a new house, he sold the old one", “لما أثترى سامي بيتا جديدا, باع "البيت القديم "W

Both the Arabic adverb "لما " and the English Adverb "when" are used in the beginning of sentences as in the example above.

\section{6 قطّ" “" "Qatt”, "Never”}

It is an adverb of the past as a matter of immersion, and it is used after negation or

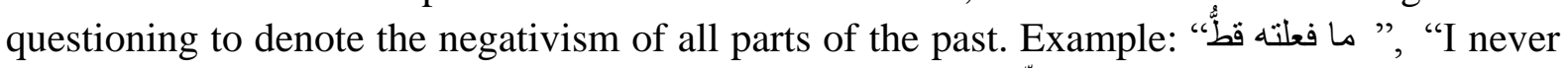

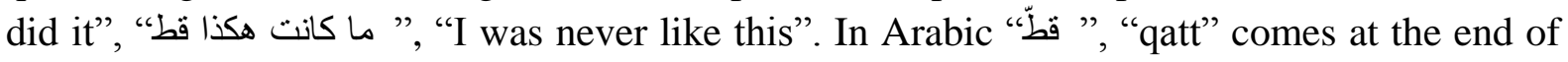
the sentences, whereas, "never" in English comes within the sentences.

\section{7 " عوْضُ"}

It is an adverb for the future as a matter of immersion, and it takes all that is received from the time, which is inflectional if it is added and it is non-inflectional if it is not added, and proceeds by negative to denote the negation of all parts of the future. 
if I said: “ل أفعله ، أولن أفعله عوْضُ" "I never do it”. The meaning I won’t do it at any time in the future. We can't say: "ما فعلته عوض " "ماضه ، "عوضُ" "I didn't do it", because the verb is in the past. " "Awadh", "never" always occurs at the end of the sentences.

In English "never" is as well a negative time adverb meaning "not at any time" but usually occurs within the sentences, examples: "Jim never comes on time", "She has never been to London". "never" could come in the beginning of the sentence in direct speech, example: "Never mind, my dear," said her father. In Arabic "عوْضُ", "Awadh", never comes at the beginning of sentences.

\section{8 "بينا وبينما", “Bina” and "Binama”, "Between” and “While”}

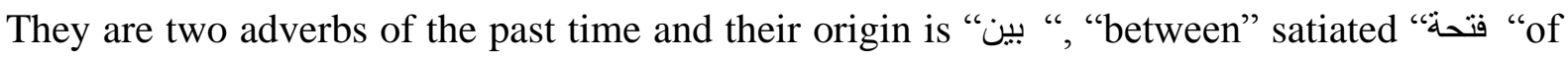

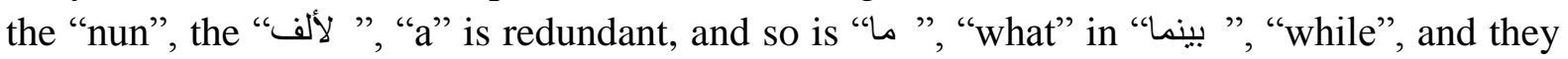
are obligated a lot to the nominal sentences and little to verbal sentences.

Originally “بين " جين الظهر والعصر “, is used for the place and used for time, such as:, "I

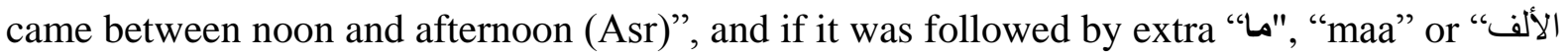
“, then it is specified for time. "While I was standing, Zayed came”.

English usage of this adverb is similar to the Arabic usage.

\section{9 "قبلُ وبعدُ" "Before and After”,}

They are two adverbs of time, set up subjective on adverbial, or genitive by "من " " "from" such as: “: جئت قبل الظهر ، أو بعده ،أو من قبله أو بعدِه "I came before or after noon, or before or

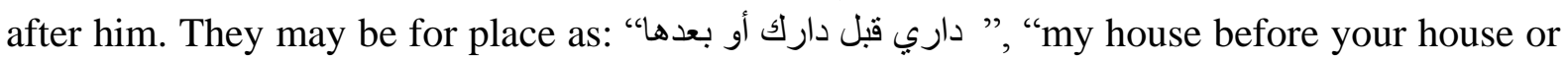
after it". They are from common adverbs.

They are indeclinable on inductive case if they are cut of the addition of in pronunciation not in the meaning, so that the addition to remains in the intention as God Almighty says: " لله الأمر ( الروم 4), "to Allah the matter from before and after", that is, before the dominance and after it, then they are cut off from the addition by the word and meaning in order to deny, so that the addition is not intended and does not notice in the mind expressed about: “ فعلت ذللك قبلاً أو بعداً ", "I did so before or after".

\subsection{0 " لادى ولان", "Ladi and Ladon”, "I Have”}

Two adverbs of time and space in the sense of (have) are indeclinable on stillness (absence of a vowel) and predominant in " لدن" that put in genitive case by "من", trom" as in Almighty says: "وعلمناه من لدنا علماً ", "and we have taught him knowledge from us" and may be put in accusative case on temporal adverb such as:"سافرت لدن طلوع الثمس ", " “ I traveled by the sunrise", or spatiality: "جلست لانكل ", "I stayed at your place".

If added to the "ياء", "yaa" of the speaker, the " نون" "Nun" is obligated to protect towards

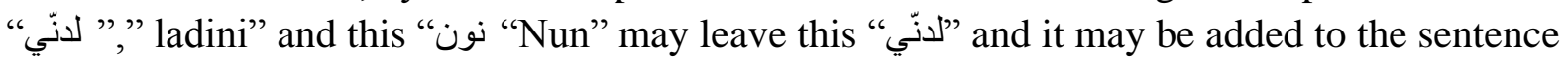
and to the single as: "انتظرتك من لدن طلوع الثمس إلى أن غربت " نون" ", "I waited for you from the sunrise until it set". 


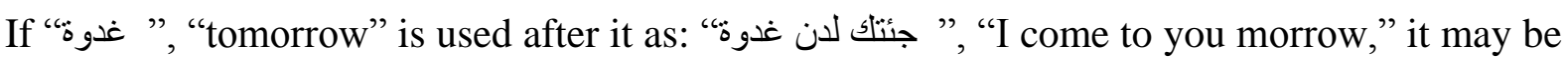
put in genitive in addition to "لدن" التمييز " لدان " to distinguish, or it could be a predicate to "كان ", "kana" figured with its name.

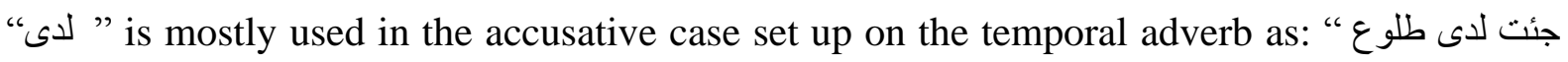

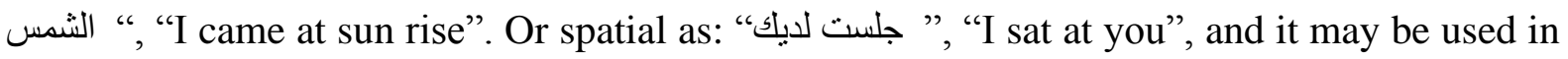

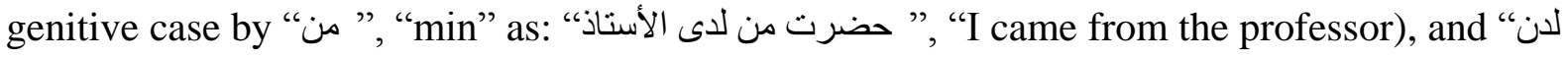

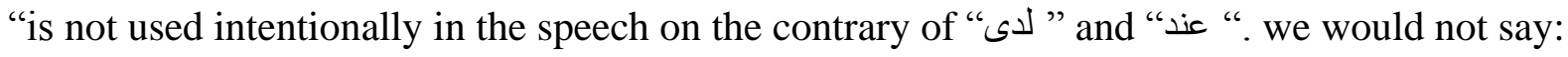

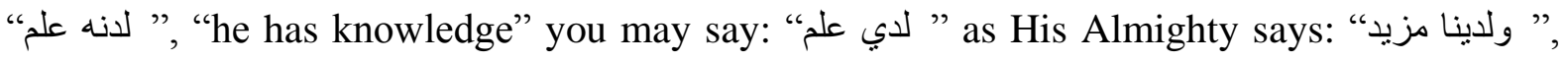
"we have more". You may say: "عنده علم ", "he has knowledge".

" لدي كتاب نافع" " are always used in the present, so we cannot say is present, whereas, "عند" is used for the presence and absence.

" may not be used in a genitive case with a preposition other than "من" لدى ولدن و عند"، "إلى" "min". it

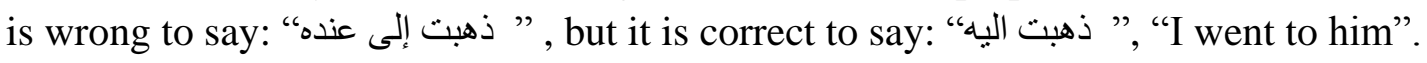

7.11 “الآنَ", “Alaan”, “Now”

" الآنَ" is an adverb of time for the time that you are in. It is indeclinable on the accusative case, and may be put in genitive by the prepositions: "من و إلى ومذ ومنذوحتى ", "from, to, from, until" indeclinable in the accusative case in the place of genitive case.

English has the same adverb with same usages. Here examples of both adverbs: "from now

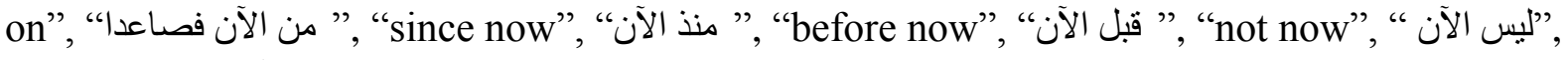
"until now", "حتى الآن"

In English the adverb of time "now" means 'at the present time' or 'at this moment'. "now" is usually used at the end of the sentence, example: "I lived in London before but I live in New

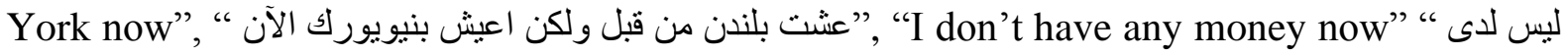

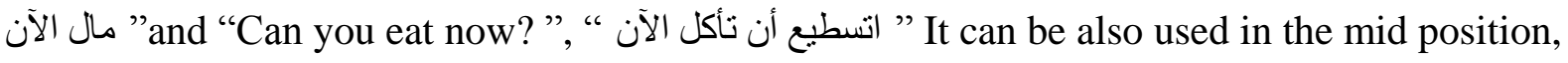
between the subject and the main verb of the sentence, example: "Sami now works in a big bank".

\subsection{2 " “" "Amas”, “Yesterday”}

“" is temporal adverb. It is indeclinable on the genitive (كسر) if it is definite i.e. indicates the day before or previous day.

It is permissible to be attached to "الالأمس", "the", "yesterday". It can be inflected unanimously, and it would be indefinite that does not indicate one day "yesterday", but rather any previous day.

English has only one usage which "yesterday" and the article "the" cannot be added to the adverb "yesterday" to become definite adverb as Arabic. 


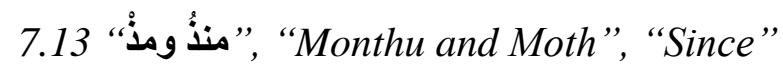

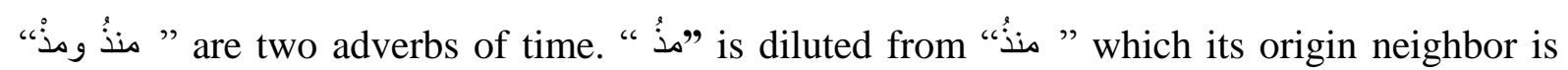

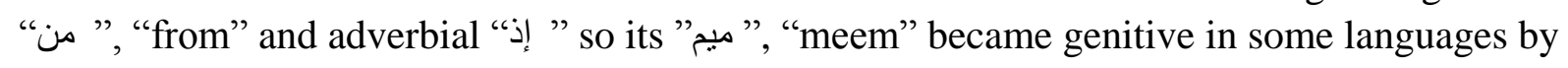
considering it original.

\section{Results}

A. Similarities between Arabic and English adverbs of time:

1. In both languages, the adverbs add information about the verb, and they are named adverbs for the occurrence of the verbs, and it is called (Adverb) in English to add information or clarification to the verb.

2. Declinable nouns in both Arabic and English can be used as nouns or as adverbs, e.g. "Tomorrow is a holiday". In this sentence "Tomorrow is a noun", but in "I see you tomorrow", "tomorrow" here is an adverb. It is exactly the same in Arabic, e.g. "غدا عطلة" ", " and " أراك غد" (2)

3. In English the Adverb of time is a word that describes: when, for how long, or how frequently a certain action occurs. "Yesterday" is used for the past. Still, while, yet, etc. are used for the present and in the future, soon, tomorrow, next week are used. Arabic adverbs of time as English adverbs indicate the time at which actions occur.

4. Both English and Arabic adverbs are usually placed at the end of the sentences, but they could be placed at the beginning of the sentences if they are important. They can be placed in the middle of sentences.

5. "منى " is an adverb of time in Arabic means "when". Both languages use this adverb exactly the same; e.g. "منى جئت ب" "When did you come?"

6. "لَّ", "lama", "when" is an adverb used for past time in both Arabic and English and are used in the beginning of sentences, e.g. "when I saw you, I felt happy”, “لمار أيتك شعرت بسعادة" “.

7. "بينا وبينما", “bina" and "binama”, "between" and "while”. Arabic and English usage of this adverb is similar, e.g. "بينما أنا سائر رأيت حادثا في الطَّريق", "While I was walking I saw an accident in the way".

8. "قفبلُ وبعدُ" "before and after" two adverbs of time in both Arabic and English. They are used exactly the same in both languages, e.g. "كنت هنالك قبل وبعد وصوله" "I "I was there before and after his arrival".

9. "الآنَ", “alaan”, "now” is an adverb of time means 'at the present time'. Arabic and English use this adverb in a similar way in different places in the sentences, e.g. "يمكنك أن تذهب " "الآن يمكنك أن تذهب" "You can go now”, "Now you can go".

10. Adverbs include the meaning of (in), otherwise they were not adverbs but rather names that have the place of expressions.

11. The pronoun of the adverb is put in genitive with a preposition in both languages. 


\section{I Macrothink}

International Journal of Linguistics

ISSN 1948-5425

2021, Vol. 13, No. 1

12. In both languages, some adverbs can be used at the beginning, middle, and end of the sentences.

B. Differences between Arabic and English adverbs of time:

1. There are some words that can deputize the adverb in Arabic, but not in English.

2. قطّّ", "qatt”, "never" is an adverb of time used after negation or questioning to denote the negativism of all parts of the past. In Arabic "قطّ" "qatt" comes at the end of the sentences, whereas, "never" in English comes within the sentences.

3. The Arabic adverb of time "عوضص", "Awadh", "never" always occurs at the end of the sentences. English "never" is as well a negative time adverb, but usually occurs within the sentences.

4. "ال" " أمس" , "amas", "yesterday" is an Arabic adverb of time similar to English, but if , "the" is added to the Arabic adverb " أمس", it would be indefinite and that does not indicate one day "yesterday", but rather any previous day and that does not exist in English.

\section{Conclusion}

The adverb of time indicates the time when the act occurred, and it is used to answer the question of" when". In this research, 13 Arabic adverbs of time were selected and were analyzed and compared to their 7 English equivalents. Although Arabic and English are from different language families, there were 12 similarities in the use of the adverb of time while there were only 4 differences. The results fulfilled and answered the research questions. It was expected that these results would be helpful for the learners as well as for the instructors by providing a good descriptive analysis of the adverbs of time in both languages. It was also expected that the learners would understand the differences and the similarities and use the similarities as a way of positive transfer as was indicated in the Contrastive Analysis hypotheses. In addition, they could use the differences to avoid the interference from the mother tongue in using the adverbs of time as well as creating an effective learning process. Furthermore, it was expected that the result of this research would be useful as a reference and an inspiration for other researchers to investigate the adverbs of time in other languages.

\section{References}

Alexander, L. G. (1988). Longman english grammar. SWTC/15 China.

Azar, B. S. (1999). Understanding and using English grammar. New York: Pearson Education.

Cinque, G. (1999). Adverbs and functional heads: A cross-linguistic perspective. Oxford: Oxford University Press.

Freeman, D. L., \& Celce-Murci, M. (1989). The grammar book. Jungle Publication.

Fries, C. (1945). Teaching and learning English as a foreign language. Ann Arbor: University of Michigan Press. 


\section{Macrothink}

International Journal of Linguistics

ISSN 1948-5425

2021, Vol. 13, No. 1

Hinkel, E. (2002). Second language writers' text: linguistic and rhetorical features. Mahwah, NJ: Erlbaum. https://doi.org/10.4324/9781410602848

Hinkel, E. (2003). Adverbial markers and tone in L1 and L2 students' writing. Journal of Pragmatics, 35(7), 1049-1068. https://doi.org/10.1016/S0378-2166(02)00133-9

Hsue-Hueh Shih, R. (2000). Compiling Taiwanese learner corpus of English. Computational Linguistics and Chinese Language Processing, 2(5), 87-100.

Jackendoff, R. (1972). Semantic interpretation in generative grammar. Cambridge, MA: MIT Press.

Koch, R. S., \& Folse, K. S. (2000). Focus on grammar an advanced course for reference and practice. New York: Pearson Education Company.

Krohn, R. (1971). English sentence structure. The University of Michigan Press.

Lado, R. (1957). Linguistics across cultures. Ann Arbor: University of Michigan Press.

Marcella, F. (1972). Modern English a practical reference guide. New Jersey: Prencite Hall.

Pérez-Paredes, P., \& Sánchez-Torne, M. (2014). Adverb use and language proficiency in young learners' writing. International Journal of Corpus Linguistics, 19(2). Https://doi.org/10.1075/ijcl.19.2.02per

Quirk, R., \& Greenbaum, S. (1973). A university grammar of English. Oxford: Oxford University Press.

Rankin, T. (2010). Advanced learner corpus data and grammar teaching: Adverb placement. In M. C. Campoy-Cubillo, B. Bellés-Fortuño, \& L. Gea-Valor (Eds.), Corpus based approaches to English language teaching (pp. 205-215). London: Continuum.

Ryding, K. C. (2005). A reference grammar of modern Standard Arabic. Cambridge Press. https://doi.org/10.1017/CBO9780511486975

Sarah, C. (1981). From grammar to paragraphs. New York: Copying by Random House.

Swan, M. (1996). Practical English usage. Oxford: Oxford University Press.

\section{Copyrights}

Copyright for this article is retained by the author(s), with first publication rights granted to the journal.

This is an open-access article distributed under the terms and conditions of the Creative Commons Attribution license (http://creativecommons.org/licenses/by/4.0/) 